\title{
NOTE / NOTE
}

\section{Foraging behaviour by gray wolves on salmon streams in coastal British Columbia}

\author{
C.T. Darimont, T.E. Reimchen, and P.C. Paquet
}

\begin{abstract}
Spawning salmon (Oncorhynchus spp.) are important resources for terrestrial ecosystems and often shape the ecological strategies of organisms with which they co-evolve. Gray wolves (Canis lupus), primarily predators of ungulates, are sympatric with salmon over large areas, but the relationship between the two remains poorly understood. We report here observations of direct and indirect evidence of salmon predation by wolves in several watersheds of coastal British Columbia and in detail report on the foraging behaviour of four wolves at one river during September and October 2001. Wolves oriented themselves upstream during detection and pursuit of salmon. The pooled mean capture rate was $21.5 \mathrm{salmon} / \mathrm{h}$ and mean efficiency (successes/attempt) was 39.4\%. In most cases, wolves consumed only heads of salmon, perhaps for nutritional reasons or parasite avoidance. Preying on salmon may be adaptive, as this nutritious and spatially constrained resource imposes lower risks of injury compared with hunting large mammals. We infer from capture rates and efficiencies, as well as stereotypical hunting and feeding behaviour, a history of salmon predation by wolves and, as a corollary, a broad distribution of this foraging ecology where wolves and salmon still co-exist.

Résumé : Les saumons (Oncorhynchus spp.) en période de fraye constituent d'importantes ressources pour l'écosystème terrestre et influencent souvent les stratégies écologiques des organismes avec lesquels ils sont en coévolution. Les loups gris (Canis lupus), avant tout des prédateurs d'ongulés, vivent en sympatrie avec les saumons sur de grandes étendues, mais la relation entre les deux reste mal comprise. Nous avons fait des observations directes et indirectes de prédation de saumons par les loups dans plusieurs bassins hydrographiques de la région côtière de la ColombieBritannique et nous décrivons ici en détails le comportement de quête de nourriture de quatre loups à une rivière, en septembre et en octobre 2001. Les loups s'orientaient vers l'amont durant la détection et la poursuite des saumons. Le taux moyen de capture, calculé sur l'ensemble des résultats, était de 21,5 saumons/h et l'efficacité moyenne (nombre de tentatives réussies/total), de 39,4\%. Dans la plupart des cas, les loups ne consommaient que la tête du saumon, peut-être pour des raisons nutritives ou pour éviter les parasites. La prédation de saumons peut être adaptative, puisque cette ressource nutritive et limitée dans l'espace est reliée à des risques réduits de blessures comparativement aux risques de la chasse aux gros mammifères. Étant donné les taux de capture et l'efficacité observés, de même que les comportements stéréotypés de chasse et de prise de nourriture, la prédation des saumons par les loups a une longue histoire, et, en corollaire, l'écologie de la quête de nourriture se fait sur une grande étendue là où les saumons et les loups coexistent.
\end{abstract}

[Traduit par la Rédaction]

\section{Introduction}

In coastal areas, important and reciprocal ecological and evolutionary interactions exist between marine and terrestrial systems. The annual migration of spawning salmon (Oncorhynchus spp.) provides nutrition to a diverse assemblage of terrestrial consumers and decomposers (Cederholm et al.
1989; Willson and Halupka 1995). The historical occurrence, nutritional value, and predictability of spawning salmon have shaped considerably the ecological strategies of organisms that co-evolved with this resource. The influences of salmon on terrestrial systems are largely dependent on a few predators that remove salmon from streams, consume a portion, and leave the remains for a diversity of users. Although red

Received 9 September 2002. Accepted 10 December 2002. Published on the NRC Research Press Web site at http://cjz.nrc.ca on 14 March 2003.

C.T. Darimont ${ }^{1}$ and T.E. Reimchen. Department of Biology, University of Victoria, P.O. Box 3020, Victoria, BC V8W 3N5, Canada.

P.C. Paquet. Faculty of Environmental Design, University of Calgary, Calgary, AB T2N 1N4, Canada, and World Wildlife Fund Canada, 245 Eglinton Avenue East, Suite 410, Toronto, ON M4P 3J1, Canada.

${ }^{1}$ Corresponding author (e-mail: cdarimon@uvic.ca). 
foxes (Vulpes vulpes), otters (Lontra canadensis), and bald eagles (Haliaeetus leucocephalus) may prey on live salmon (Gard 1971), black and brown bears (Ursus americanus and Ursus arctos) are recognized as the dominant predators and vectors that transfer nutrients from salmon into terrestrial systems (Reimchen 1994, 2000; Hilderbrand et al. 1999).

Gray wolves (Canis lupus) are sympatric with salmon over large areas of western North America, but the relationship between the two remains poorly understood. Wolves are primarily predators of ungulates but show considerable breadth of diet, including scavenging carrion (Young and Goldman 1944; Mech 1970; Paquet and Carbyn 2003). Brief descriptions of salmon as a food resource for wolves exist (Young and Goldman 1944; Mech 1977; Mech et al. 1998). The remains of salmon have been identified in scat (Kohira and Rextad 1997; Darimont et al. unpublished data), and stable isotope analysis indicated that salmon could provide considerable lifetime dietary protein to wolves in Alaska and British Columbia (Szepanski et al. 1999; Darimont and Reimchen 2002). However, neither scat-based nor isotope-based studies can differentiate between scavenging and predation.

Wolves are elusive, often nocturnal, and intolerant of humans, thereby limiting opportunities for behavioural observations. Whether the relationship between wolves and spawning salmon is best defined by scavenging or predation is unclear. Herein we report indirect evidence of wolves consuming salmon in several watersheds of coastal British Columbia and the first detailed observations of a group of wolves actively preying on spawning salmon. We present capture rate and efficiency data, examine spatial orientation of wolves relative to stream flow during detection and pursuit of salmon, and discuss some ecological and evolutionary implications of this predator-prey relationship.

\section{Materials and methods}

During summers of 2000 and 2001, we surveyed more than 75 watersheds, many salmon-bearing, on British Columbia's central and north coast for the presence of wolves (Darimont and Paquet 2002). Examination of salmon carcasses in watersheds where we detected abundant wolf sign suggested consumption of salmon by wolves. These initial observations led us to focus on the Kunsoot River, Denny Island $\left(52^{\circ} 09^{\prime} \mathrm{N}, 128^{\circ} 01^{\prime} \mathrm{W}\right)$, where a rendezvous site used by a group of at least three adults and three pups was nearby. Annual returns of salmon to this watershed during the 1990s averaged 2000 chum salmon (Oncorhynchus keta) and 5500 odd-year pink salmon (Oncorhynchus gorbuscha). During our monitoring sessions and estuary searches, we did not detect bears or their sign but river otters and eagles were present. Neither coyotes (Canis latrans) nor red foxes occur in the area (Nagorsen 1990).

We visited the estuary on 20 days between 7 September and 4 October 2001 (total $62.5 \mathrm{~h}$ ) during low to mid-tides and when wind blew downstream to conceal our presence. We observed wolves fish at only one site, upstream from us and where water depth varied between 5 and $50 \mathrm{~cm}$, depending on microsite substrata, tide, and recent rainfall. Twentyfour monitoring sessions occurred during daylight and four during darkness.
After several minutes of scanning the estuary with binoculars, we (maximum two observers) moved quietly and slowly to observational sites concealed by vegetation 60 or $120 \mathrm{~m}$ downstream from the fishing site, depending on wind speed. Our ability to detect approaching wolves at night was limited by our vision and our presence then may have displaced or prevented wolves from fishing.

On 5 days, we observed an adult female, adult male, and two unsexed pups capture salmon. Twelve fishing bouts occurred on these 5 days between 0700 and 0905 and most involved the adult female and one pup. We recorded all bouts in entirety except one, before which a wolf had already captured at least one salmon. Lengths of bouts were variable and ranged from 2.5 to $60.5 \mathrm{~min}(\bar{x}=23.0 \mathrm{~min}$, standard deviation $(\mathrm{SD})=20.1 \mathrm{~min})$.

Immediately following 15 monitoring sessions distributed throughout the study, we counted and marked all new salmon carcasses by cutting tail fins longitudinally and noted which portions were consumed. We searched the entire estuary, including areas beyond view of our observation site because wolf scats, tracks, and vocalizations indicated activity upstream.

We recorded $4.6 \mathrm{~h}$ of fishing behavior with a Sony VX2000 video camera using a 5-10× zoom lens. We distinguished wolves by differences in pelage, size, and urination behaviour. We defined a capture "attempt" as a determined movement toward a salmon, a "capture" when a wolf removed a salmon from the stream, and "handling time" as the duration between capture and the return of the wolf to the stream. Capture rate for each wolf was calculated as the number of salmon per hour and efficiency as the number of captures per attempt using bouts as independent cases. When possible, we also compared orientation of wolves relative to direction of water flow during detection and pursuit of salmon using attempts as independent cases. Statistical tests were performed using SPSS (v. 10.1).

\section{Results}

Wolves demonstrated a stereotypical sequence during detection, capture, and subjugation stages of hunting salmon at the Kunsoot River. Wolves approached a target salmon (typically two to five steps), plunged their muzzle into the water to capture the fish with their teeth, and trotted to shore to consume it (Fig. 1). Orientation of head and ears suggested that visual and auditory modalities were used. Wolves remained motionless (5\% of attempts), walked (43\%), trotted $(47 \%)$, or ran $(5 \%)$ during pursuit. Most salmon were consumed on grass next to the river ( $70 \%$ of captures), but others were transported by wolves into the forest or estuary beyond our view. Adults consumed exclusively the head portion of every salmon they captured $(n=57)$ before resuming fishing; pups consumed the head portions of only 7 of 12 (58\%) captures but consumed no portion of the other five. Mean handling time was $72 \mathrm{~s}$ (range 15-150 s). We observed six cases of wolves scavenging salmon carcasses, including portions other than heads, particularly at the beginning of bouts by adults and by pups while adults fished.

Capture rates and efficiencies were relatively high but varied between age classes. We observed 251 attempts that re- 
Fig. 1. Adult female gray wolf (Canis lupus) capturing a pink salmon during detection (a), capture (b), and subjugation $(c)$ stages on Denny Island, coastal British Columbia, during the fall of 2001.

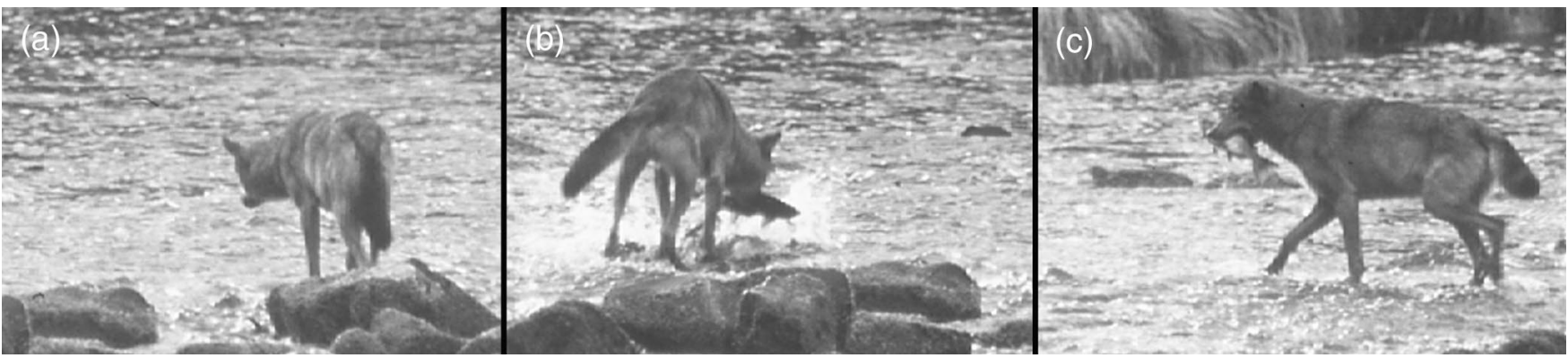

sulted in 99 captures. The pooled mean capture rate was $21.5 \mathrm{salmon} / \mathrm{h}$ and mean efficiency was $39.4 \%$. Differences in capture rates between age classes approached significance $\left(\bar{x}_{\text {adult }}=27.1 \mathrm{salmon} / \mathrm{h} ; \bar{x}_{\text {pup }}=13.0 \mathrm{salmon} / \mathrm{h} ;\right.$ Student's $t$ test, $P=0.06)$. Capture efficiencies for adults were much higher than for pups (49.1 vs. $12.6 \%$; Student's $t$ test, $P=$ 0.008).

Wolves searched for and pursued salmon in a relatively conservative manner with respect to stream flow. For the two wolves we observed most, orientation of body axis was biased upstream during detection (adult female, $\chi^{2}=85.03$, $P<0.001$; pup $1, \chi^{2}=19.43, P<0.001$ ) and pursuit (adult female, $\chi^{2}=79.97, P<0.01$; pup $\left.1, \chi^{2}=19.14, P<0.01\right)$. Pup 2 oriented upstream during detection $\left(\chi^{2}=14.73, P<\right.$ $0.01)$ but only generally so during pursuit $\left(\chi^{2}=7.46, P=\right.$ $0.06)$. The adult male showed no pattern in orientation during detection $\left(\chi^{2}=4.55, P=0.103\right)$ or pursuit $\left(\chi^{2}=1.27\right.$, $P=0.529$ ).

We noted a continual but variable accumulation of fresh carcasses during the study. On 12 of 15 searches, we observed fresh carcasses for a total of 720 salmon (0-202 carcasses/ search; $\bar{x}=50.7, \mathrm{SD}=59.6$ ). Consistent with direct observation of feeding, every fresh carcass we inspected had tissue missing from the head area. On some carcasses $(n=\sim 30)$, other smaller portions were also removed.

Our coastwide observations of wolf activity during salmon migration matched the patterns we observed at the Kunsoot River. At three separate watersheds, C.T. Darimont and others (I. McAllister, personal communication; G. Pfleuger, personal communication) witnessed brief but similar stereotypical fishing behaviour. At these sites, and in others where sign indicated continued presence of wolves, fresh salmon carcasses showed the same pattern of tissue consumption.

\section{Discussion}

Across their holarctic distribution, wolves have adapted to hunt diverse prey, including spawning salmon. Their prey differ greatly in size, avoidance, and defense strategies, from birds and rodents to bison (e.g., Carbyn and Trottier 1987; Kohira and Rextad 1997; Paquet and Carbyn 2003). Although they co-exist over large areas, the contribution of migrating salmon as food for wolves and the ecological context in which consumption may occur is largely unknown. Mech (1970) suspected that fish contributed little to the diet of wolves, perhaps because detailed studies had not occurred where wolves had access to spawning salmon. Recent scat- and isotope-based analyses (Kohira and Rextad 1997; Szepanski et al. 1999; Darimont and Reimchen 2002) have identified salmon in the diet of wolves, although scavenging was not differentiated from predation. Previous reports of wolves preying on fish exist (Young and Goldman 1944; Kuyt 1972; Bromely 1973; P. Paquet, personal observation), but our detailed observations and carcass examinations confirm that wolves can be efficient predators of salmon and that predation occurs seasonally over several weeks at the Kunsoot River and likely elsewhere.

Preying on salmon may have considerable adaptive value for wolves. Avoiding dangerous ungulate prey in favor of a less dangerous alternative such as salmon is consistent with foraging theory predictions (Stephens and Krebs 1986). Wolves risk severe injuries (Rausch 1967; Pasitschniak-Arts et al. 1988; Mech and Nelson 1990) and death (Stanwell-Fletcher 1942; Frijlink 1977; Nelson and Mech 1985; Mech and Nelson 1990; Weaver et al. 1992) when hunting ungulates. Also, because salmon are typically abundant and spatially constrained, they require less search effort once located than do ungulate prey, for which wolves may travel extensively (e.g. Musiani et al. 1998).

The upstream-biased orientation of wolves during detection and pursuit likely minimizes detection by prey. Salmon generally maintain their position heading against stream current. Visual, lateral line, and especially olfactory cues to salmon may be reduced when a wolf ambushes from downstream and behind the fish.

Consumption by wolves of salmon heads was disproportionate to other body parts, and this pattern appears widespread. Wolves used only the head portion of all salmon captured and consumed $(n=64)$. Similarly, Young and Goldman (1944) quoted a biologist in Alaska who observed wolves that "had taken salmon...eating only their heads". Headless salmon carcasses found upstream at the Kunsoot River and elsewhere where wolf sign was abundant but where we did not directly observe foraging strongly suggested wolves were preying on salmon. We note, however, that bears and other carnivores also prey on salmon and may selectively consume the head (but see following discussion regarding different tissue consumption by bears).

Multiple processes may be involved in a preference for head tissue. Consuming only energetically valuable portions of a prey item may maximize net returns, particularly if prey is abundant and easily captured (e.g., Sih 1980). Black bears on Haida Gwaii, B.C., also preferentially take the lipid-rich brain of freshly captured salmon, but consume eggs, and 
dorsal and lateral trunk musculature as well (Reimchen 2000). In addition to calories, bears and wolves may also be targeting specific nutrients in salmon heads (Gende et al. 2001). Docosahexaenoic acid, an omega-3 fatty acid, is essential for nervous system function, can be obtained only from diet, and occurs in high proportion in brain and optic tissue (Horrocks and Yeo 1999; Connor et al. 2001). In addition, animals often make foraging decisions to minimize exposure to parasites (Lozano 1991; Hart 1994). Salmon can be infected by Neorickettsia helminthoeca via a trematode vector (Nanophyetus salmincola). Neorickettsia helminthoeca causes "salmon poisoning disease", which can be fatal to canids (Young and Goldman 1944; reviews in Philip 1955; Knapp and Millemann 1970). Metacercariae of $N$. helminthoeca occur in the head and dermal tissue of salmon but are thought to concentrate in kidney and muscles of infected fish (Bennington and Pratt 1960; Baldwin et al. 1967). Reports of this parasite exist throughout the Pacific Basin from the conterminous United States to far eastern Russia (Witenberg 1932; Knapp and Millemann 1970; Booth et al. 1984). Young and Goldman (1944) suggested that salmon poisoning influenced wolf abundance and might have been responsible for the almost total disappearance of wolves from Oregon by the early 1890s.

Abandoned portions of salmon carcasses contribute to coastal ecosystem processes. Transfer of salmon to terrestrial systems by wolves, bears, or other predators makes nutrients available via scavengers, decomposers, and faecalurinary deposition, thus adding nitrogen and phosphorus to typically nutrient-limited coastal ecosystems (Reimchen 1994, 2000; Ben-David et al. 1998; Willson et al. 1998; Hilderbrand et al. 1999).

Observations of predation may provide insight into historical encounters between predator and prey (Vermeij 1982). Although these preliminary observations were limited in scope and duration, we infer from capture rates and efficiencies, as well as from stereotypical hunting and feeding behaviour, a history of salmon predation by wolves. As a corollary, and supported by indirect evidence gathered during our coastwide surveys, we suggest a broad distribution of this trophic interaction. We are currently testing this hypothesis with expanded behavioural observations combined with scat- and isotope-based approaches. Where wolves and salmon are still sympatric, salmon may be an important seasonal resource, perhaps disrupting seasonally the tight ecological association between wolves and ungulates (Mech 1970; Paquet and Carbyn 2003).

\section{Acknowledgments}

We thank the Heiltsuk Nation for permission and support to undertake research in their Traditional Territory. We are much obliged to the Raincoast Conservation Society for financial and logistical support, as well as to numerous colleagues in the field, especially Johanna Gordon-Walker, Gudrun Pfleuger, and Chester Starr. Merav Ben-David provided constructive comments on the manuscript. While preparing the manuscript, C.T.D. was supported by a Natural Sciences and Engineering Research Council of Canada (NSERC) Industrial Postgraduate Scholarship, and T.E.R. by NSERC Operating Grant NRC2354 and funds from the David Suzuki Foundation.

\section{References}

Baldwin, N.L., Millemann, R.E., and Knapp, S.E. 1967. "Salmon poisoning" disease. III. Effect of experimental Nanophyetus salmincola infection on the fish host. J. Parasitol. 53: 556-564.

Ben-David, M., Hanley, T.A., and Schell, D.M. 1998. Fertilization of terrestrial vegetation by spawning Pacific salmon: the role of flooding and predator activity. Oikos, 83: 47-55.

Bennington, E.E., and Pratt, I. 1960. The life history of the salmonpoisoning fluke, Nanophyetus salmincola (Chapin). J. Parasitol. 46: 91-100.

Booth, A.J., Stogdale, L., and Grigor, J.A. 1984. Salmon poisoning disease in dogs on southern Vancouver Island. Can. Vet. J. 25: 2-6.

Bromely, R.G. 1973. Fishing behavior of a wolf on the Taltson River, Northwest Territories. Can. Field-Nat. 87: 301-303.

Carbyn, L.N., and Trottier, T. 1987. Responses of bison on their calving grounds to predation by wolves in Wood Buffalo National Park (Alberta, Canada). Can. J. Zool. 65: 2072-2078.

Cederholm, C.J., Houston, D.B., Cole, D.L., and Scarlett, W.J. 1989. Fate of coho salmon (Oncorhynchus kisutch) carcasses in spawning streams. Can. J. Fish. Aquat. Sci. 53: 154-164.

Connor, W.E., Anderson, G.J., and Lin, D.S. 2001. Dietary n-3 fatty acid deficiency and its reversibility. In Fatty acids. Physiological and behavioural functions. Edited by D.I. Mostofsky, S. Yehuda, and N. Salmen, Jr. Human Press, Totowa, N.J. pp. 177-192.

Darimont, C.T., and Paquet, P.C. 2002. The gray wolves, Canis lupus, of British Columbia's Central and North Coast: distribution and conservation assessment. Can. Field-Nat. 116: 416-422.

Darimont, C.T., and Reimchen, T.E. 2002. Intra-hair stable isotope analysis implies seasonal shift to salmon in gray wolf diet. Can. J. Zool. 80: 1638-1642

Frijlink, J.H. 1977. Patterns of wolf pack movements prior to kills as read from tracks in Algonquin Park, Ontario, Canada. Bijdr. Dierkd. 47: 131-137.

Gard, G. 1971. Brown bear predation on sockeye salmon at Karluk Lake, Alaska. J. Wildl. Manage. 35: 193-204.

Gende, S.M., Quinn, T.P., and Willson, M.F. 2001. Consumption choice by bears feeding on salmon. Oecologia, 127: 372-382.

Hart, B.L. 1994. Behavioural defenses against parasites: interaction with parasite invasiveness. Parasitology, 109: S139-S151.

Hilderbrand, G.V., Hanley, T.A., Robbins, C.T., and Schwartz, C.C. 1999. Role of brown bears (Ursus arctos) in the flow of marine nitrogen into a terrestrial ecosystem. Oecologia, 21: 546-550.

Horrocks, L.A., and Yeo, Y.K. 1999. Health benefits of docosahexaenoic acid (DHA). Pharmacol. Res. 40: 211-225.

Knapp, S.E., and Millemann, R.E. 1970. Salmon poisoning disease. In Infectious diseases of wild mammals. Edited by J.H. Davis, L.H. Karstad, and D.O. Trainer. Iowa State University Press, Ames. pp. 332-342.

Kohira, M., and Rextad, E.A. 1997. Diets of wolves, Canis lupus, in logged and unlogged forests of southeastern Alaska. Can. Field-Nat. 111: 429-435.

Kuyt, E. 1972. Food habits and ecology of wolves on barrenground caribou range in the Northwest Territories. Can. Wildl. Serv. Rep. Ser. No. 21.

Lozano, G.A. 1991. Optimal foraging theory: a possible role for parasites. Oikos, 60: 619-640.

Mech, L.D. 1970. The wolf. The ecology and behavior of an endangered species. Natural History Press, Doubleday, New York.

Mech, L.D. 1977. Where can the wolf survive? Natl. Geogr. Mag. 1977 (October).

Mech, L.D., and Nelson, M.E. 1990. Evidence of prey-caused mortality in three wolves. Am. Midl. Nat. 123: 207-208. 
Mech, L.D., Adams, L.G., Meier, T.J., Burch, J.W., and Dale, B.W. 1998. The wolves of Denali. University of Minnesota Press, Minneapolis.

Musiani, M., Okarma, H., and Jędrzejewski, W. 1998. Speed and actual distances travelled by radiocollared wolves in Białowieża Primeval Forest (Poland). Acta Theriol. 43: 409-416.

Nagorsen, D. W. 1990. The mammals of British Columbia: a taxonomic catalogue. Mem. No. 4, Royal British Columbia Museum, Victoria, B.C.

Nelson, M.E., and Mech, L.D. 1985. Observations of a wolf killed by a deer. J. Mammal. 66: 187-188.

Paquet, P.C., and Carbyn, L.N. 2003. Gray wolves. In Mammals of North America. Revised ed. Edited by G. Feldhamer and B. Thompson. John Hopkins University Press, Baltimore, Md. In press.

Pasitschniak-Arts, M., Taylor, M.E., and Mech, L.D. 1988. Skeletal injuries in an adult arctic wolf. Arct. Alp. Res. 20: 360-365.

Philip, C.B. 1955. There's always something new under the "parasitological" sun (the unique story of helminth-borne salmon poisoning disease). J. Parasitol. 41: 125-148.

Rausch, R.A. 1967. Some aspects of the population ecology of wolves, Alaska. Am. Zool. 7: 253-265.

Reimchen, T.E. 1994. Further studies of black bear and chum salmon in stream and estuarine habitats at Bag Harbour, Gwaii Haanas. Canadian Parks Service Technical Report, Queen Charlotte City, B.C.

Reimchen, T.E. 2000. Some ecological and evolutionary aspects of bear-salmon interactions in coastal British Columbia. Can. J. Zool. 78: 448-457.
Sih, A. 1980. Optimal foraging: partial consumption of prey. Am. Nat. 116: 281-290.

Stanwell-Fletcher, J.F. 1942 Three years in the wolves' wilderness. Nat. Hist. 49: 1-7.

Stephens, D.W., and Krebs, J.R. 1986. Foraging theory. Monogr. Behav. Ecol., Princeton University Press, Princeton, N.J.

Szepanski, M.M., Ben-David, M., and Van Ballenberghe, V. 1999. Assessment of anadromous salmon resources in the diet of the Alexander Archipelago wolf using stable isotope analysis. Oecologia, 120: $327-335$.

Vermeij, G.J. 1982. Unsuccessful predation and evolution. Am. Nat. 120: 701-720.

Weaver, J.L., Arvidson, C., and Wood, P. 1992. Two wolves, Canis lupus, killed by a moose, Alces alces, in Jasper National Park, Alberta. Can. Field-Nat. 106: 126-127.

Willson, M.F., and Halupka, K.C. 1995. Anadromous fishes as keystone species in vertebrate communities. Conserv. Biol. 9: 489497.

Willson, M.F., Gende, S.M., and Marston, B.H. 1998. Fishes and the forest. Expanding perspectives on fish-wildlife interactions. BioScience, 48: 455-462.

Witenberg, G. 1932. On the anatomy and systematic position of the causative agent of so-called salmon poisoning. J. Parasitol. 18: 258-263.

Young, S.P., and Goldman, E.A. 1944. Wolves of North America. Dover Publications, New York. 